\title{
FISHERIES IN SMALL RESERVOIRS IN NORTHERN GHANA: Incidental Benefit or Important Livelihood Strategy
}

\author{
Jennifer Hauck \\ Department for Environmental Politics \\ Helmholtz Centre for Environmental Research (UFZ) \\ Leipzig, Germany \\ Email: jennifer.hauck@ufz.de
}

\section{ABSTRACT}

Fisheries in small reservoirs in the Upper East Region are perceived to be an incidental benefit and the potential of this livelihood strategy is neglected. However, in some communities fishing in small reservoirs is part of their livelihood strategies. Several participatory appraisal tools provided entry points for investigations, and supported quantitative surveys, which investigated the number of fishermen and fishmongers, prices of fish, demand for fish and the income derived from fishing and selling fish. For most of those involved in fisheries, the income from these activities is not incidental, but among the three most important livelihood strategies and the income from fishing is lifting about $15 \%$ of the economically active male population in the study communities out of absolute poverty. The number of fishmongers and their income are much lower, yet many women rank the income from fishmongering high, and their growing number shows the attractiveness of the activity. Based on these findings this paper recommends to expand government as well as donor efforts to train members of those communities which are currently not able to access fisheries resources to support their livelihoods because of the lack of know-how and fishing gear.

KEY DESCRIPTORS: Fisheries, Upper East Region, poverty, malnutrition, income

\section{INTRODUCTION}

In the Upper East Region of Ghana hundreds of small multi-purpose reservoirs were built during the past 60 years (Baijot, Moreau \& Bouda, 1997; Braimah, 1990). They help a steadily growing rural population to overcome water scarcity and at the same time to create new income sources. Fishing and fish farming in these reservoirs were at best perceived to be of incidental benefit, based on assessments like that of Dickson and Benneh (2004: 60-61) that "River fishing is taking place in northern Ghana where it is done mainly by the groups of Ewe fishermen who have migrated there from the Volta Region. The northern Ghanaians themselves are not particularly interested in fishing." Further, Essuman (1992) and Ackah and Appleton (2003), for example, explain that the fish supply to northern Ghana and the consumption of fish there is low, since people produce and prefer to consume meat. Apart from that, COFAD (2002: 97) notes that:

Inland capture fisheries have received less development assistance than other sectors of primary production, whether from African governments or from aid agencies. Reasons why the sector has been kept out of the mainstream of development include the low degree of socio-political representation of the fishers as well as the fact that inland fisheries are mostly part of the informal sector of the economy.

Based on the assumptions that fishing as an activity and fish for consumption is not popular in northern Ghana and the fishers have no lobby, most policy makers and international donors neglect development of fisheries activities in the reservoirs.

However, Armar-Klemesu, Rikimaru, Kennedy, Harrison, Kido and Takyi (1995) found that even though almost every household raises animals such as cows, goats, sheep, and fowl, these are rarely 
eaten but sold in times of need. The analysis of the Ghana Living Standard Surveys 3 and 4 (GSS, 2000) shows increasing household expenditures on fish in the Upper East Region (UER). Further, evidence was found that certain fisheries activities in shallow seasonal water bodies have a long history in northern Ghana, and communities which were taught how to use modern fishing equipment quickly picked up the practice (Hauck \& Youkhana, 2010).

This is not surprising, as malnutrition in Ghana is most prevalent in the form of Protein Energy Malnutrition (PEM), which causes growth retardation, underweight (Van de Poel, Hosseinpoor, JehuAppiah, Vega \& Speybroeck, 2007). Yet, fisheries activities continue to be neglected and the number of people who are dependent on fishing in northern Ghana is unrecorded (World Bank, 2007) as well as catch figures or incomes derived from this activity.

Considering the high levels of poverty and malnutrition, a livelihood strategy that could help to fight these conditions deserves more attention. The purpose of this paper is to provide some insights into the relevance of fisheries in small reservoirs and selling the fish in comparison with other livelihood strategies as well as the demand of fish in the UER of Ghana.

\section{LIVELIHOOD STRATEGIES IN THE UPPER EAST REGION OF GHANA}

As the title of this paper suggests people in the UER pursue livelihood strategies, ways of combining and using assets - that are open to them in pursuit of beneficial livelihood outcomes that meet their own livelihood objectives (DFID, 1999). A number of these strategies are often combined to cope with and adapt to an ever increasing number of shocks and stresses that the people are exposed to (Ellis, 2000; Bacho, 2004), However, some strategies are more important than others. In the following some of the strategies that people in the UER pursue are described to provide a background for classifying the importance of fisheries in small reservoirs and selling fish for local livelihoods.

In their analysis of food security and vulnerability Biederlack and Rivers (2009) found that in the UER $90 \%$ of the households citing food crop production (including home gardening) as one of their three main livelihood activities. Besides its popularity, agriculture is associated with a range of problems and might become even more challenging with changing climate. Administrators and farmers claim that the overall quantity of rain falling is declining and that the distribution is more unfavorable and more unreliable than before (Laube, 2007). Detailed analyses of climatic patterns in the context of the GLOWA Volta Project confirm change. Kunstmann and Jung (2005: 85), for example, state:

Historical temperature time series showed clear positive trends at high levels of statistical significance. Among precipitation time series, most significant trends were negative. Results [...] show that in April, which is the usual transition from the dry to the rainy season, precipitation will decrease by up to $70 \%$ and the duration of the rainy season will narrow, which may have extensive implications for agriculture. While the predicted total annual precipitation increases only slightly (5\%), the increase in surface runoff is $18 \%$. Predicted temperature increase in the rainy season is up to $2^{\circ} \mathrm{C}$.

However, the consequences of climate change for the region are discussed controversially. Blench (2006), for example could neither find inter-annual nor intra-annual changes in rainfall patterns or temperatures. Yet he admits that in general crops are prone to the erratic climate.

Uncertain climate is, however, not the only challenge for the livelihood strategy. Agricultural land is, due to inheritance patterns, subject to fragmentation and the average size of a compound farm has reduced to less than an acre (Hardiman, 2003; Gyasi, 2005). Due to unequal distribution, many compounds have not enough land to keep a family. Paid labor, usually on the farms belonging to wealthier compounds, is playing an increasingly important role. 
Another bundle of problems is associated with the structural adjustment in Ghana starting in the early 1980s. The Structural Adjustment Programs (SAP) were based on an export-growth model (Holtkamp, 1994), including liberalization of the economy, reduction of the civil service by $15 \%$, the elimination of subsidies (Massing, 1994). One of the consequences of these developments was the concentration of national resources in the export-oriented cocoa, timber and mining sectors (Tonah, 1994), which are all located in the southern regions of Ghana.

The losses of the structural adjustment for the north were considerable as the main livelihood basis of the north, the local-supply oriented agricultural sector, was neglected in favor of the exportoriented agricultural sector and industry in the south. Expensive input prices resulting from removal of subsidies and poor extension services, exacerbated by poor weather in the 1990s, led to declining output and while poverty for the rest of the country declined, poverty in northern Ghana increased (Hesselberg \& Yaro, 2006).

The liberalization policies and austerity measures in the context of the SAPs had also considerable impacts on the prices for agricultural produce, and Ghanaian farmers now have to accept considerable seasonal fluctuations of prices. Prices peak usually in the hunger season when food is short and are very low after harvesting (Gyasi, 2005). Irrigated crops, such as tomatoes or leafy vegetables, are even more affected by the seasonal variability in price due to their short shelf life (Gyasi, 2005). These fluctuations are fortified by the dictated prices of the world market. For example, rice is produced in many countries with high subsidies. Their vast surpluses are sold on the world market at dumping prices, and it is difficult for local rice farmers in northern Ghana to compete (Laube, 2007). The import of rice from Asia and the USA has led to the abandonment of many rice farms in northern Ghana (Yaro, 2007).

Many households try to improve their situation with horticulture. Blench (2006) assumes that Muslim migrants such as the Hausa introduced horticulture practices in shallow rivers and seasonally flooded land, where farmers irrigate by fetching water from wells and streams using buckets and hollow gourds. Today, traditional leafy vegetables are supplemented with high value crops such as rice, onions, tomatoes, pepper, cabbages, and lettuce (Gyasi, 2005). Dry-season gardening is recognized to have the potential to contribute to poverty eradication by implementing water harvesting strategies such as reservoirs and attached irrigation schemes. In their analysis of satellite images of the Upper East Region in the rainy season Liebe, van de Giesen and Andreini (2005) found a total of 504 reservoirs, however, especially the 348 reservoirs with an acreage of less than 1 ha are often flat seasonal water bodies that formed in water-logged depressions. Yet, this leaves more than 150 reservoirs, ranging from 1 to 35 ha, with a total surface area of 999.54 ha (Liebe et al., 2005). Unfortunately the water productivity of these reservoirs is still rather low, due to insufficient management (Mdemu, Rodgers, Vlek \& Borgadi, 2009). Further, due to the limited size of the irrigation schemes, the plots are hard fought over, and considerable conflicts about land and water distribution are widespread, often catalyzed by ethnical or political rivalries (Gyasi, 2005; Bacho and Bonye, 2006).

Apart from agriculture and horticulture 19\% of the households citing livestock production and animal husbandry as one of the three main livelihood activities of their households. Livestock keeping, especially small ruminants (sheep, goats, pigs) as well as poultry (chickens, guinea fowl, and pigeons), represents a major coping strategy in times of need, for example after a crop failure (Blench, 2006) as the animals can be sold. Unfortunately, most household have the priority is to invest in the size of the herd rather than on the quality of the stock, which leads in many cases to overstocking (Dickson and Benneh, 2004).

Migration, seasonal but increasingly permanent is another very important livelihood strategy for households in Northern Ghana. Seasonal migration from the north to the south started as forced labor migration under the colonial rule. Soon, the relative wealth of the southern forest zone in 
terms of gold mining, timber and cocoa has created an important magnet for surplus labor from the savannas, especially in the dry season (Blench, 2006). Most of the migrants return at the beginning of the rainy season to their farms in the north where they invest their wages. However, based on the consequences of structural adjustment, land pressure, intergenerational conflicts and other reasons migration increasingly takes on aspects of permanence (Grindal, 2003; Meier, 2003; Hesselberg and Yaro, 2006).

Migration is not the only changing strategy. Yaro (2007) found that there is a growing commercialization of livelihood strategies. He found that in the 1970s, most households only engaged in natural resource gathering activities for non-commercial purposes. In more recent years, women increasingly engage in commercial trading, and as a result there are hundreds of small community markets, which serve as assembling points for surrounding communities or, in larger communities, the surrounding sub-communities (Dickson and Benneh, 2004; Gyasi, 2005). Further Bacho (2004) describes a number of small scale off-farm activities that form an integral part of the livelihood portfolios, which are undertaken as supplementary activities during the dry season, when virtually all farming activities except livestock rearing have stopped. Activities mentioned are catering services, charcoal burning or crafts.

There are a number of other traditional activities which may be called incidental benefits, rather than reliable livelihood strategies. Hunting terrestrial wildlife in the past buffered the impact of environmental or other shocks by providing bush meat for animal protein and income in times of economic hardship or food scarcity (Barrett and Arcese, 1998; Milner-Gulland et al., 2003; Dickson and Benneh, 2004). However, due to the massive decline in wildlife biomass (Brashares, Arcese, Sam, Coppolillo, Sinclair \& Balmford, 2004) it is very doubtful whether hunting is more than an incidental benefit today. Further, the literature review also revealed that, contradicting common assumptions, fishing has a place in the traditional livelihood portfolio of households in the UER. Some geological layers of the region seal parts of the surfaces and runoff water builds shallow ponds in depressions. These water bodies are naturally stocked with fish. Fortes (1937) and Klages (1953) report that these ponds have always been used for fishing before they dry up in the course of the dry season, either by hand or using traditional gear. Such activities can be considered as incidental benefits as they are limited to only a few months in the year. However, it is the purpose of this paper to investigate, whether the status of fishing as a livelihood strategy has changed based on the potentials for fishing provided by small reservoirs.

\section{MATERIALS AND METHODS}

A preliminary survey was conducted in the UER in August and September, 2006. Based on information derived from 20 interviews with scientists and technical and extension staff of the Ministry of Fisheries as well as with other key informants 70 reservoirs were selected for a site visit. The primary goal was to identify reservoirs, which reservoirs are used for fishing by the residents of the nearby communities. During these visits, semi-structured interviews were conducted with fishermen, fishmongers, dam caretakers and local authorities. Only 33 of the visited reservoirs had a fishing community, or at least one or two fishermen. However, three reservoirs were identified and selected for in-depth studies (Figure 1), which had an active fishing community using a small reservoir for fishing, but also other activities such as irrigation and cattle watering. The first reservoir was Kajelo, in Kajelo community of the then Kassena-Nankana (now Kassena-Nankana West) District. A second reservoir lies within Binduri community in the Bawku Municipality. A third reservoir lies on the border between the Bongo District and the Talensi-Nabdam District. The latter is shared by two communities, Dasabligo community in the Talensi-Nabdam District and Atonbogoro community in the Bongo District. 


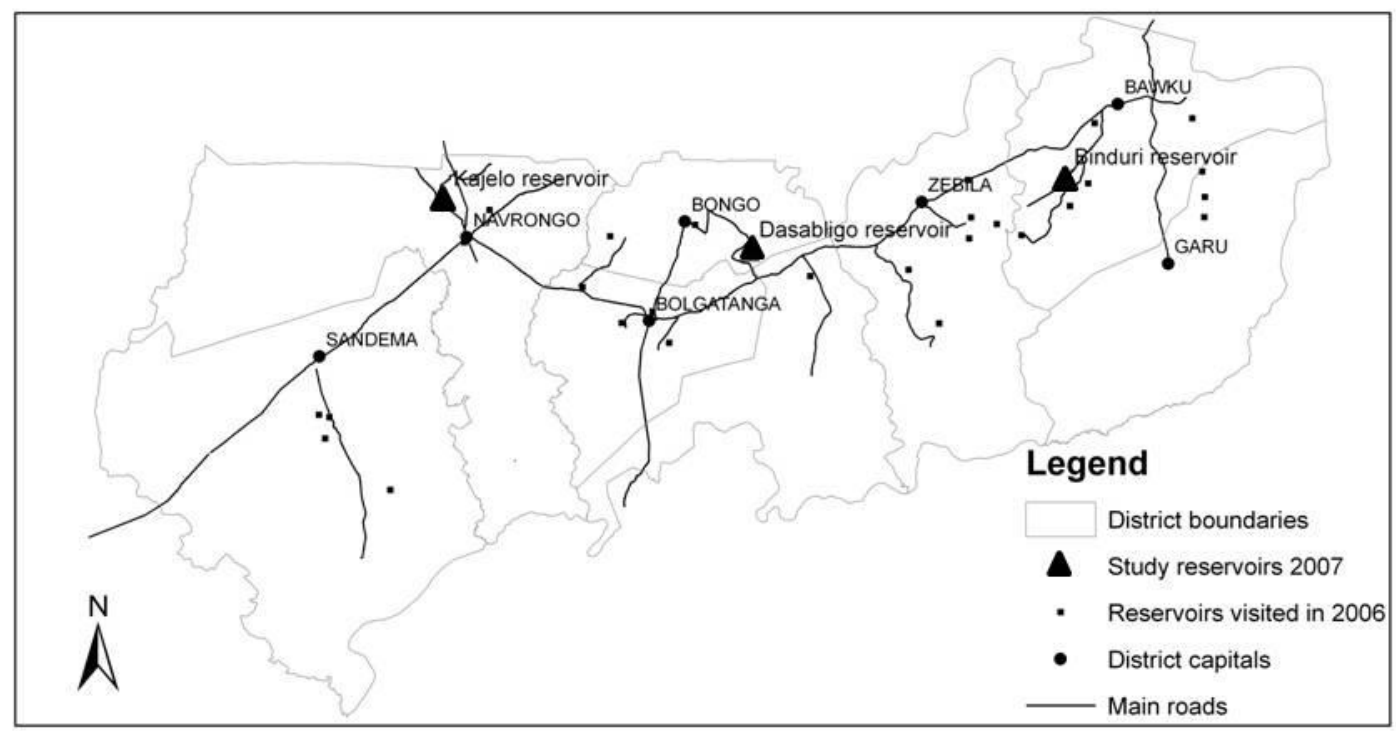

Figure 1: Map of the Upper East Region with research sites. Source: Field Surveys 2007.

The in-depth studies took place between February and August 2007 and April and May 2008. Several participatory appraisal tools, such as semi-structured interviews, focus group discussions, timelines, strategy and problem rankings provided entry points for investigations and supported the quantitative surveys. During these preparatory investigations, it turned out, that in Kajelo there are a number of fishermen, who are only fishing in the medium size reservoir Tono. In Dasabligo and Atonbogoro there were likewise a number of fishermen who only go fishing in the Red Volta River. The fishermen, who were not at all fishing in the small reservoirs, were excluded from the investigation as the subject matter of the research was fisheries in small reservoirs. Beyond that the surveys included all fishermen and fishmongers from the selected sites (Table 1).

Table 1: Number of interview partners

\begin{tabular}{|c|c|c|c|}
\hline Community & Total number of fishermen & $\begin{array}{c}\text { Number of fishermen } \\
\text { interviewed }\end{array}$ & $\begin{array}{c}\text { Number of mongers } \\
\text { interviewed }\end{array}$ \\
\hline Kajelo & 139 & 73 & 20 \\
\hline Dasabligo & 59 & 38 & 8 \\
\hline Atonbogoro & 44 & 33 & 35 \\
\hline Binduri & 66 & 52 & 25 \\
\hline
\end{tabular}

Source: Field Survey, 2007.

Information was collected on the number of fishermen and fishmongers, their age, ethnicity, literacy, religion, and the income derived from fishing and selling fish. Further, the women were asked to indicate a trend of the demand for fish.

Two strategies were used to get estimates on incomes from fishing. First, fishermen were asked during the survey to provide estimates about their income in the dry season 2007, in the rainy season 2007 and the dry season 2008. Second, the results were discussed in focus group interviews with a 20-30 fishermen in the study communities. 
Fish is a perishable good, and its marketing can be difficult, especially in places without access to electricity and cooling facilities, such as the study communities. In order to evaluate the prospects and challenges of fishmongering, data about market structures, types and prices of fish, as well as demand for fish were collected at Binduri, Akayonga and Paga markets were investigated.

Data were analyzed using MS Excel and tools of qualitative content analysis.

\section{RESULTS}

\section{Number and characteristics of fishermen and fishmongers}

In Kajelo, $3 \%$ of the total population goes fishing in the reservoir. However, the community is close to a larger reservoir - Tono Dam, where fishing also takes places. Including the fishermen who fish in Tono, the number raises to $5 \%$. The percentages for Dasabligo and Atonbogoro are similar, when fishermen who fish in the nearby Red Volta River are included.

In Binduri, the number of fishermen in relation to the total population is much lower, since there are no other fishing opportunities. Although the White Volta River is close by, the fishermen in Binduri report that their skills are not suitable for the deep and fast flowing water. Fishing activities provide in average $15 \%$ of the economic active men with an alternative livelihood strategy. This is more than incidental, especially when considering that the strategy can be pursued regularly throughout the dry season, when other activities are usually scarce. Yet, in order to make a proper judgment, the income derived from the activity also needs to be taken into consideration.

Table 2: Number of fishermen per community in relation to the total and male population

\begin{tabular}{|l|c|c|c|c|c|}
\hline Community & Total pop. & $\begin{array}{c}\text { Economic } \\
\text { active men. }\end{array}$ & $\begin{array}{c}\text { All fisher- } \\
\text { men }\end{array}$ & $\begin{array}{c}\text { \% of all } \\
\text { fishermen of } \\
\text { tot. pop. }\end{array}$ & $\begin{array}{c}\text { ofl } \\
\text { fishermen of } \\
\text { economic } \\
\text { active men }\end{array}$ \\
\hline Kajelo & 2685 & 650 & 139 & 5 & 21 \\
\hline Dasabligo & 1364 & 328 & 59 & 4 & 18 \\
\hline Atonbogoro & 1152 & 276 & 44 & 3 & 16 \\
\hline Binduri & 10500 & 2325 & 66 & 1 & 3 \\
\hline Average & 3925 & 895 & 77 & 3 & 15 \\
\hline
\end{tabular}

Source: Field survey, April and May 2007.

The analysis of the questionnaire data reveals that the average age of the fishermen in Kajelo is 32 years, with an average of 3.5 years of education. While all 73 fishermen interviewed are Kassena, their religious affiliation is more divers. The majority of $60 \%$ follow traditional beliefs, while $14 \%$ are Catholics. $10 \%$ are Muslims and $16 \%$ belong to free churches.

In Dasabligo, there are a total of 59 fishermen, although only 38 of them were interviewed as they go fishing in the Dasabligo reservoir frequently. In Atonbogoro, there are in total 44 fishermen of whom 33 were interviewed. The majority of the fishermen of Dasabligo are Nabdam (90\%) and only $10 \%$ are Gurensi. Also, $73 \%$ of the fishermen in Atonbogoro are Gurensi while $21 \%$ are Nabdam. The remaining $6 \%$ are Bossi, an ethnic group of the Bongo area who are related to the Gurensi. The average age of the fishermen in Dasabligo is 40 years and in Atonbogoro 37 years. Most of the 
fishermen of Dasabligo are illiterate, only four have basic or higher education while only one was still at school at the time of the interview. The situation is hardly better in Atonbogoro, where also only five can read and write. Religious diversity is very low amongst the fishermen of the Dasabligo reservoir: $93 \%$ of the Atonbogoro fishermen are traditionalists, while $7 \%$ are Catholics. In Dasabligo, $86 \%$ are traditional believers, $9 \%$ are Catholics and $5 \%$ are Muslims.

In comparison to the total population, the total number of fishermen of 66 is small, and only 52 fishermen use the Binduri reservoir. Most fishermen live in the sub-communities surrounding the reservoir. On ethnicity, 26 of the fishermen are Kusasi, 11 are Yarsi, eight are Mamprusi, four are Busanga and three are Moshi. On religion, 18 of the fishermen are Christians, 19 are Muslims, and 15 follow traditionalists. The average age of the fishermen is, with 44 years, high and corresponds to the high labor-migration of young males. The high average age is surprising, as fishing is a very exhausting activity and most fishermen retire early. Due to a misunderstanding of the questionnaire, no data about the educational level of the fishermen were collected. From personal observation and comments during group discussions it can be assumed that most fishermen are illiterate.

Apart from a common low literacy, the analysis shows that the fishermen communities are mostly heterogeneous in age, ethnicity and religion. While the fishermen in all communities were anxious to assure that the diversity in ethnicity and religion never caused any problems, the generation gap frequently caused trouble, as the younger fishermen often refused to listen to the older fishermen.

Hesselberg and Yaro (2006) found that women increasingly engage in cash-income earning activities. This is also reflected in the number of fishmongers in the four communities. The fishmongers of Kajelo and Dasabligo comprise about $1 \%$ of the total population. Atonbogoro has the highest percentage of fishmongers, $2 \%$ of the total. The 35 fishmongers in Binduri comprise $0.3 \%$ of the total population (Table 3). While, current numbers suggest that fishmongering is rather an incidental benefit, as only a few women engage in this activity, a number of women involved in trading in fish from the small reservoirs is steadily increasing (Figures 2, 3 and 4).

Table 3: Number of fishmongers per community in relation to the total and female population.

\begin{tabular}{|l|l|l|l|l|l|}
\hline & & & & & \\
Community & Total pop. & Female pop. & Mongers & $\begin{array}{l}\text { \% of mongers } \\
\text { of tot. pop. }\end{array}$ & $\begin{array}{l}\text { \% of mongers of } \\
\text { female pop. }\end{array}$ \\
\hline Kajelo & 2685 & 1386 & 20 & 1 & 1 \\
\hline Dasabligo & 1364 & 708 & 8 & 1 & 1 \\
\hline Atonbogoro & 1152 & 603 & 25 & 2 & 4 \\
\hline Binduri & 10500 & 5850 & 35 & 0.3 & 1 \\
\hline
\end{tabular}

Source: Field survey, May and June 2007. 


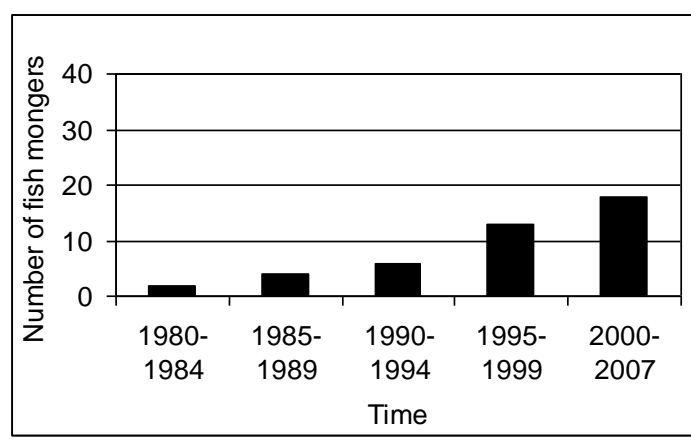

Figure 2: Number of fishmongers over time, Kajelo.

Source: Field survey, May and June 2007.

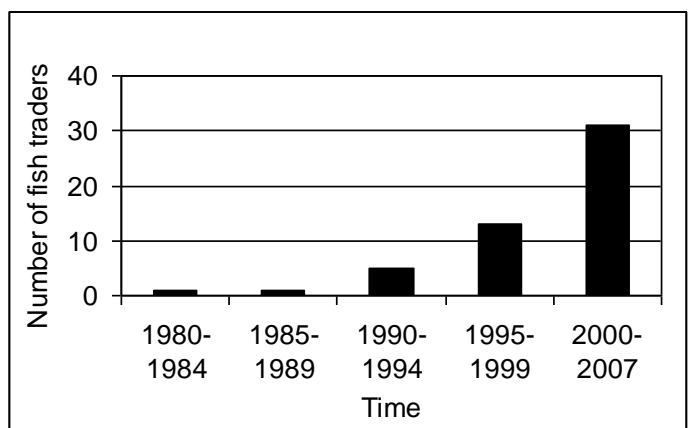

Figure 3: Number of fishmongers over time, Dasabligo and Atonbogoro.

Source: Field survey, May and June 2007.

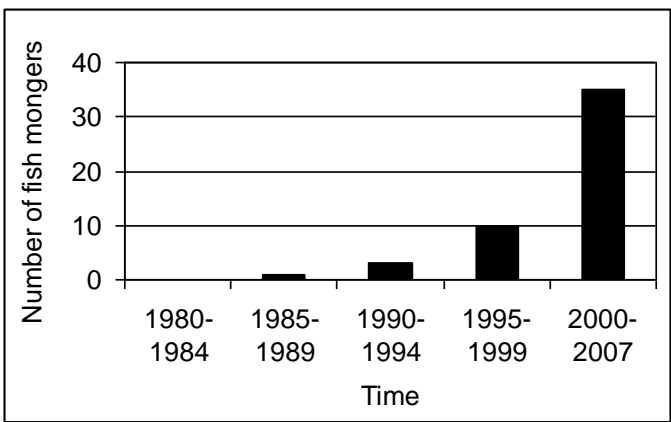

Figure 4: Number of fishmongers over time, Binduri.

Source: Field survey, May and June 2007.

Like in the rest of Ghana (Atta-Kesson and Atuguba 2007), all involved in trading fish in Kajelo and the other communities are female. The average age of the women in Kajelo is with 37 years higher than that of the fishermen. The women are all Kassena, and are organized in an informal group to share their experiences, exchange advice, and discuss prices. The educational level is with over $60 \%$ illiterates low; $40 \%$ have an average education of 6 years. On religion, $17 \%$ are traditionalist $22 \%$ are Catholics, $17 \%$ are Muslims and $44 \%$ belong to various free churches.

The fish mongers from the communities Dasabligo and Atonbogoro work independently from each other. There are 8 fish mongers in Dasabligo of whom 7 are Nabdam and one is a Gurensi. In Atonbogoro there are 25 mongers, $76 \%$ of them are Gurensi and only $6 \%$ are Nabdam. The average age of the fish mongers is 36 and most of them are illiterate; only four have primary education. Apart from one Muslim, the women all follow traditional beliefs.

In Binduri, 35 women declared themselves fish mongers. During the field research, the women formed a group with regular group meetings, where experiences and advice can be exchanged regularly. The average age of the women of 32 years is lower than that of the fishermen. Only eight of the women are not illiterate. On religion, 13 are Christians, 18 are Muslims and only four are traditionalists.

\section{Livelihood strategy rankings}

Fishing as a livelihood strategy has two main components. First, fishermen fish in order to sell the catch and earn income. Second, in addition to income generation, many fishermen fish in order to provide their families with protein. The share of what is sold and what is kept for home consumption varies from one fisherman to another and more importantly, with the season. The end of the dry 
season in April and May, when all the harvest products are consumed or saved as input for the farming season that starts in April and May is called the hunger season (Norton, Bortei-Doku Aryeetey, Korboe \& Dogbe,1995; Hesselberg \& Yaro, 2006). In order to bridge the hunger gap during this period, the majority of the fishermen sell most of their catch to buy staple foods such as millet or corn.

Figure 5 below shows that almost all of the fishermen still depend on rain-fed farming as their most important livelihood activity and only about $20 \%$ rank fishing above farming. Most of the fishermen rank fishing as the second most important livelihood strategy. A little over $40 \%$ of the fishermen have a third livelihood strategy mostly in the form of dry season gardening in the irrigation perimeter behind the reservoir dam wall. Most of the fishermen in Binduri own an irrigation plot and rank gardening higher than fishing. One fisherman from Binduri explained: "With the farming and gardening, we earn money all at once when we sell it. This money we need to buy fertilizer, seeds and other inputs for our farms or gardens or to roof our houses. With fishing we earn only little money at a time, which we use to feed our families."

Figure 5: Livelihood strategy ranking of fishermen from the 4 communities.
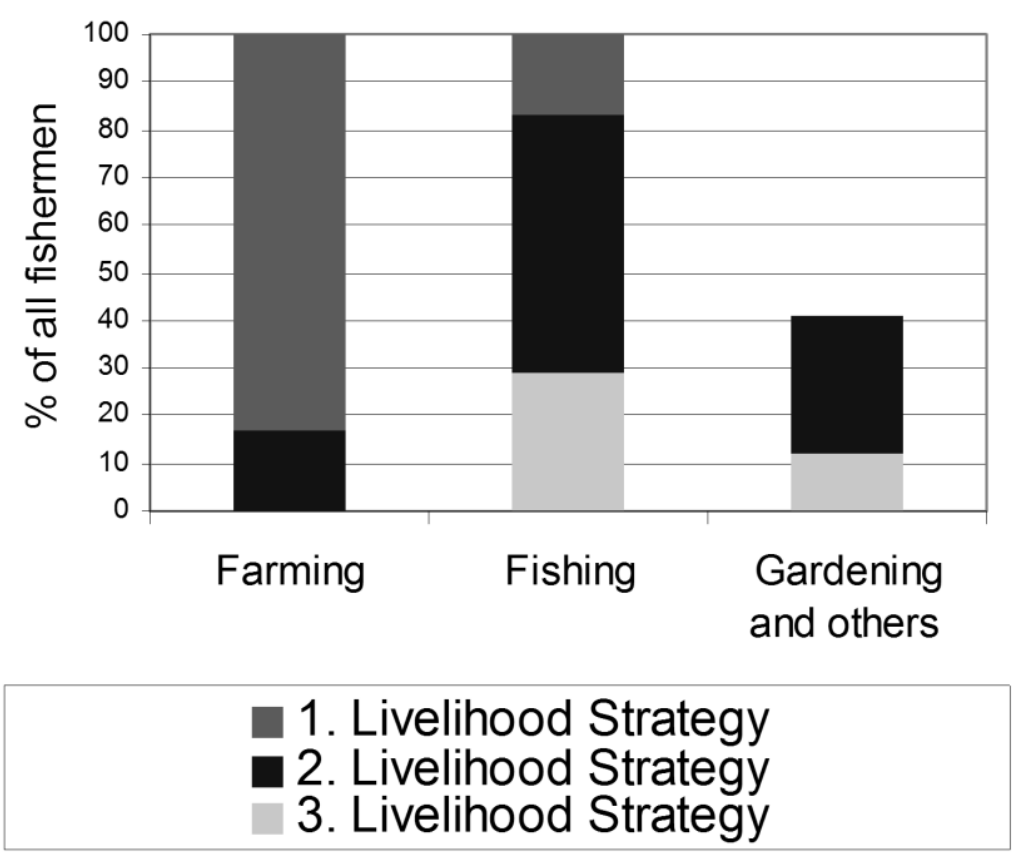

Source: Field survey, April and May 2007.

Only few fishermen reported other activities. A few fishermen stated that sometimes they migrate in the dry season. One fisherman from Dasabligo explained that: "When the dry season starts, we go test fishing in the Red Volta. If catches are good, we stay at the Red Volta and earn money with fishing. If catches are poor, we travel to nearby towns to work there. In 2007, catches were poor so I decided to travel to Bawku to push carts in the market."

Although most men indicated rain-fed farming as their most important livelihood strategy, they also explained that the importance of the strategies is changing with the season. While in the rainy season most of the men spend their working hours on the farm, and only go fishing two to three times a week, they go fishing five to six times a week in the dry season. Not only does the number of fishing days change with the season, but also the fishing location. In the rainy season, fishermen fish in seasonal streams and close-by standing water bodies but migrate to more distant water bodies in the dry season. 
Dry-season gardening is a time-consuming activity, which follows a strict schedule and, once the plants start growing, much attention must be paid to every-day watering and frequent weeding. Yet, since the fishing activities can be handled flexibly there is usually no conflict of workloads but instead activities complement each other. Like the workloads, the income from the different activities is also complementarily used to invest in other activities. Many fishermen pointed out that in years with bad harvests the money from fishing not only helps to buy food, but also to buy inputs for their farms. In turn, the money earned with farming and gardening is often used to buy fishing gear or material to mend broken nets.

The livelihood strategy ranking of the fishmongers was done as a group exercise and the rankings were split according to season. The groups in Kajelo, Dasabligo and Atonbogoro ranked the selling of fish among their most important livelihood strategies although following the supply patterns of fish, trading becomes less important in the rainy season. In the rainy season, farming takes the topmost priority. It was only in Binduri community that none of the women attached high rankings to selling fish. In the rainy season, the trading of fish was not even among the 10 most important strategies and in the rainy season the activity only ranks sixth. One possible reason is that fish supply is lower in Binduri compared to the other communities Kajelo, Dasabligo and Atonbogoro, where fishermen can access larger water bodies such as Tono or the Red Volta River.

It is interesting to note that especially the women did not only point out the increased income from fishing as very important to them, but especially the improved diets of their families. The women in all communities explained that a share of the catch, which they buy from the fishermen, is not sold but kept for the family meals. According to the women, this improved the health of their families, but unfortunately no research could be done to investigate to what extent the consumption of fish improved the health of the people.

\section{Income derived from and assets needed for fishing and selling fish}

In the dry season of the year 2007, the approximate average income from fishing was one Ghana cedi (GHC1.00) per capita per day. In the dry season of 2008 the average catch was slightly higher, due to torrential rains during the previous year (i.e., 2007). Hence, incomes increased to an approximate average of GHC1.50 per capita per day and in some cases to GHC2.00 per capita per day in Binduri.

The national poverty threshold in Ghana is GHC1.47 per capita per day. Extreme poverty starts with an income of less than GHC288.00 per adult per year or GHC0.78 per capita day (GLSSV 2005/2006 cited in Biederlack and Rivers, 2009). Consequently, even in bad years, the men live above the lower poverty line of GHC0.78 per capita per day in the dry season. In a good year, the men can live above the national poverty threshold of GHC1.47 per capita per day, at least in the dry season. During the group meetings with the fishermen in all four communities, fishermen explained that in the rainy season they only go fishing for subsistence purposes and hardly sell any fish.

Another advantage of fishing as an additional income strategy is that the running costs are low compared to farming and gardening. Once the initial investment in the purchase of nets is done, costs only occur for mending when a net tears. Sacrifices, such as chicken or flour, for better catches are made by some fishermen, but are not a necessity. Next to the gear, fishing requires certain skills. Apart from fishing and net construction skills, swimming skills are helpful. However, all experienced fishermen stated that they were ready to train those interested.

Average profits of fishmongers were around GHC20.00 per capita per month in the dry season of the year 2007 and around GHC6.50 per capita per month in the rainy season in 2006. No figures were 
collected in 2008. Their income was less than that of the fishermen, and the initial investment before the fish can be sold is comparatively high. Yet, the women in Kajelo, Dasabligo and Atonbogoro explained that they prefer selling fish to most other activities, as the workload was lower than, for example, preparing food for sale, producing shea butter or brewing pito ${ }^{13}$. Fishmongers further stated an increased share of fish for their families as a reason to enter this business.

\section{Market structures and fish products in the Upper East Region}

The investigations in Binduri, Akayonga and Paga markets provided a surprise, since in all three markets the number of fishmongers who traded freshwater fish was rather low. Only 21 of the 88 women (see Table 3) were found selling fish from the reservoirs at the three markets, most of them in Paga. After the analysis of the questionnaires of the 88 women, it turned out that especially the women from Binduri, Dasabligo and Atonbogoro travel long distances on foot to sell the fish in other markets, as the prices for fish on the local markets are low. One woman from Dasabligo explained the situation as follows: "Most families around the reservoir have at least one fisherman and are supplied with fish frequently and do not have to buy it."

The women from Atonbogoro sell fish either at the Kongo or Zebilla market, which are directly located along the Bolgatanga - Bawku road. Wholesalers from Bawku and Bolgatanga usually visit these road markets early in the morning to buy the freshwater fish in balk and resell it bits or pieces, smoked or fresh, in urban markets. The same applies to many fishmongers of Binduri, about $80 \%$ of who sell smoked fish. They prefer to walk $8 \mathrm{~km}$ to the road market in Bazua instead of selling fish in Binduri itself. In Kajelo women who live closer to Paga sell their fish at the Paga market, while women closer to Navrongo prefer to sell fish there.

In addition to freshwater fish, three other fish products (anchovies, sun-dried freshwater fish, and iced fish) were sold at all the three study markets. In total, 77 women sold fish, of which $49 \%$ (see Figure 6 below) sold anchovies, which are dry-smoked to very low moisture content. The anchovies are caught, for example, in the Keta Lagoon, which gave them their local name "Keta school boys" or merely "Keta boys". The sources of anchovies in the UER usually vary with the quantity a woman can afford to buy. Wealthier women travel to the big fish markets in southern Ghana, or at least halfway to Techiman to purchase larger quantities. Most women, however, cannot afford to travel and thus purchase fish in small quantities from the nearest bigger wholesale markets.

Small pieces of sun-dried freshwater fish called "French fish" are also sold, almost always together with or as substitute for the anchovies. It is called French fish, since it is imported from the surrounding francophone countries. Sources or species could not be identified. A small but increasing number of women sold iced marine fish, which comes iced and packed in cartons and is sold either fried as a snack or smoked as an ingredient for soups and stews.

\footnotetext{
${ }^{13} \mathrm{~A}$ local/traditional alcoholic drink of northern Ghana made from malted guinea corn (sorghum).
} 


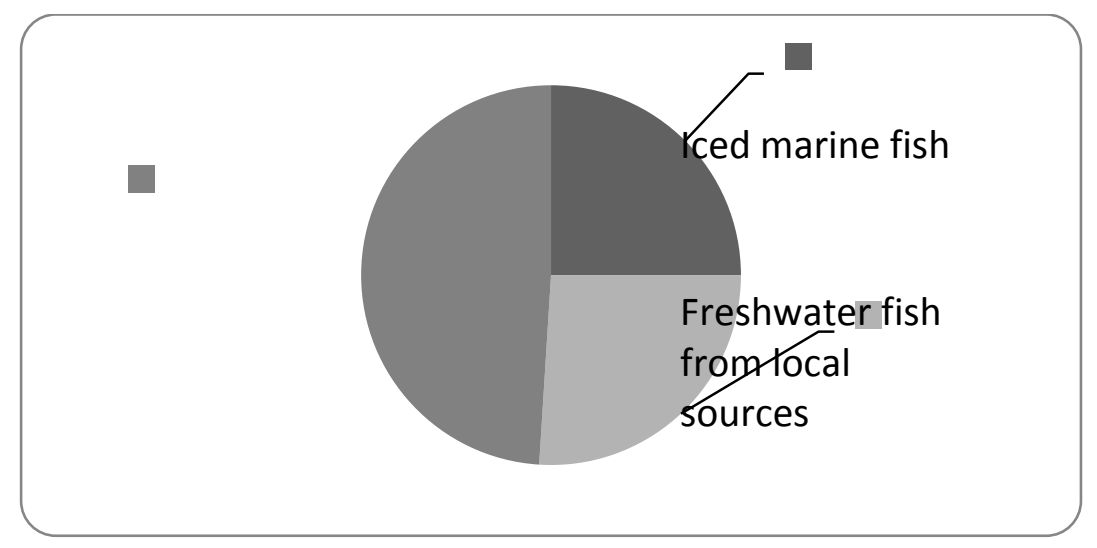

Figure 6: Percentage of women selling different fish products. Source: Field Surveys 2007.

The species sold as iced fish are mainly cheap species like mackerels and sardinellas. Ghana is only $60 \%$ fish self-sufficient as such fish is imported to fill deficits (Mensah, Koranteng, Bortey \& Yeboah, 2006). This holds true for the species mentioned above, and a fishmonger from Bolgatanga confirmed in an interview that frozen fish comes according to the labels on the cartons from EU countries, Russia, South America, Mauritania, Angola, Namibia and Senegal. The interviewed fishmonger owned a large cooling facility and was the major supplier of iced fish in the UER. Small scale fishmongers, who sold iced fish at the Akayonga market, traveled to Bolgatanga every market day to buy the iced fish from the wholesaler. There was also an intermediary wholesaler of iced fish in Paga, who also obtained her fish in Bolgatanga. She started her business five years ago, and as the business flourished she became the supplier of more than 10 new fishmongers who sold iced fish at Paga. This is a rapid development, especially considering that the price of iced fish has also increased rapidly and investments for transportation are high.

Apart from wholesale, the anchovies were sold in small quantities, which were not weighed but measured in small heaps or bowls of different sizes or estimated by hand. They were sold either in small transparent bags, leaves, or newspaper. The most common units sold were 10, 20 or 50 pesewas (100 Pesewas $=$ GHC1.00). Prices are fixed but amount and quality of the fish varies with the season. On average in 2007, 10 pesewas bought about $25 \mathrm{~g}$ of anchovies. Apart from seasonal fluctuations, fishmongers who have been in the business for a long time reported a steady increase in prices, which was mainly attributed to population growth and increasing demand.

The freshwater fish was also sold in heaps. For instance, four or five tilapia is sold for 10 or 20 pesewas per heap, depending on heap size. The catfishes were usually much bigger and cost about 50 pesewas and more. The average weight of fish purchased for 10 pesewas was $35 \mathrm{~g}$, dried or fried. The fact that the freshwater fish was cheaper than the anchovies can be attributed to the fact that there were no costs for transportation, which accrued with all other products.

Iced marine fish are cut in small pieces and sold fresh, fried or smoked. Others are sold whole fresh, smoked or fried with prices varying with size of between 30 and 50 pesewas.

\section{Demand for fish in the Upper East Region}

Fish is a primary source of animal protein in Ghana (Brashares et al., 2004). It is consumed by the majority of people ranging from the rural poor to the urban rich (Antwi, 2006). The comparison between the Ghana Living Standards Survey 3 and 4 by Ackah and Appleton (2003) shows that the expenditure shares of households for fish increased even in the UER, despite rising prices for fish. Biederlack and Rivers (2009) provide data on the consumption of fish in northern Ghana. They found 
that, on average, people eat fish 5.4 days per week, while meat is consumed 2 days per week. While they admit that their data might be biased because they included fish that was eaten as a condiment, this shows that there is a high demand for fish in the UER.

A growing demand for fish was also observed during the field research. Almost all fishmongers interviewed reported an overall increase in demand for all types of fish, although they could not specify how much, as they did not keep records. According to the fishmongers the fish was sold more quickly and especially for fish from local sources the high demand was exceeding the supply by far. A few consumers who were interviewed also stated increased fish consumption. However, again they could not specify in quantitative terms the increase in demand, as they did not keep records of their household consumption. They also stated that their purchasing power for fish was limited in favor of staple food. This was supported by rough estimates of their weekly food expenditures, which reveal that the share of money used to purchase fish was much lower than $5 \%$. Unfortunately, the limited time allocated for this work did not allow a representative survey of fish consumers.

What made fish very popular, according to the consumers interviewed, was that it could be bought in small quantities and usually served as a condiment. There was also a growing awareness that for health reasons, animal and especially fish protein should be part of the diet. The awareness was raised by radio programs, during NGO training programs and/or through school children who pass on to parents and family members. An increased availability of fish through improved transport and distribution systems and a resulting habit to consume fish also was said to have contributed to the increasing demand.

\section{Problems associated with fishing as a livelihood strategy}

There are several health issues that are associated with fishing. An Extension Officer interviewed explained that:"The fishermen are in the dirty water all the time. They get all types of diseases; sometimes they don't even know that the water makes them sick until it is too late." This has been confirmed by Hunter (2003) who found an immediate rise in endemic parasitic diseases, especially schistosomiasis (bilharzia), with a three-fold increase in schistosomiasis only a couple of years after reservoir construction. Other diseases, which have been found to spread dramatically, in the same area of northern Ghana, include malaria, lymphatic filariasis (elephantiasis), and dracunculiasis (guinea-worm disease) (Hunter, 2003).

Two of the group discussions with the fishermen described another common health problem, which often occurs at the beginning of the fishing season in January and February. Water and air temperatures are low during the night, and fishermen suffer from common colds accompanied by fever that cost them several working days.

Many of the retired fishermen explained that they had to stop fishing because of spinal disorders. One old fisherman in Kajelo explained: "We stand in the cold water all the time, throwing the wet net that is heavy and bend down to inspect the net for fish. I had to stop because my back was hurting all the time."

Many of the reservoirs are also home to small freshwater crocodiles. Several fishermen in Kajelo community reported attacks from small freshwater crocodiles. During the field research in 2008 , one fisherman was bitten in the Kajelo reservoir and he stated: "The bites are not deep, but with the open wounds I cannot enter the water to fish. So I sit at home idle and have to wait until my leg has healed."

More problematic than the health issues are, according to the group discussions with fishermen in all four communities, the dwindling catches in terms of numbers of fish but also in overall size. Years 
with low rainfall, which are increasing according to the fishermen, are followed by periods of bad catch. But also the increasing number of fishermen was mentioned as part of the problem of declining catch.

The group discussions also revealed the limited availability of gear as very problematic. The gear can only be obtained in Bolgatanga and sometimes Tamale, where they are also relatively cheaper compared to local markets.

As mentioned above, in comparison with other livelihood strategies, selling fish is more comfortable, as the commodity is sold quickly and the women have more time to do their own shopping and go home early. Some women also explained that processing the fish is not as hard as producing kenkey or shea butter, and the smoked fish is not heavy and can easily be carried to the markets even when they are distant. Further, once the initial investments were covered, the women were satisfied with their profit margins. The growing number of fishmongers, however, increased the competition for fish supplies and thus reduced profit margins. Another problem is that fish is a perishable good. Even when smoked, it can be kept only for some days, and if the markets were poorly attended the fishmongers could make losses, which, according to the women, happened from time to time.

\section{CONCLUSIONS AND RECOMMENDATIONS}

The aim of this study was to assess how fishing in small reservoirs influences local livelihoods in order to check the common assumptions that people in the Upper East Region of Ghana neither know how to fish nor do they eat fish. These assumptions have led to an almost complete neglect of fisheries development in northern Ghana, both by national governments and international donors while the fish production from many community reservoirs, due to lack of expertise and resources, remains poor or low. Since this situation inhibits fisheries development as one option for alterative income generation, these assumptions need to be re/examined.

The income from fishing in the study communities is lifting about $15 \%$ of the economically active male population in the study communities out of absolute poverty. In dry seasons, which follow ample rainfall, fishing yields enough income to lift the men above the national poverty threshold of GHC1.47 per capita per day.

While income from fishing alone does not ensure the total escape from poverty, it provides the possibility to diversify income. Through a diversified income, households become less vulnerable to the failure of their other livelihood strategies and due to the alternative income sources in the dry season, the need for seasonal migration can be reduced. Furthermore, it helps the fishermen and their families to bridge the dry and, more important, the hunger season, when other income sources are scarce and all other resources have to be invested into rain-fed farming.

Drawing from the interviews, it can be concluded that fishing not only serves as an income source, but also improves diet. While the actual contribution of higher fish consumption of the households with fishermen and fishmongers was not measured, especially women were convinced about the positive health impacts, also contributing to the high ranking of the livelihood strategy.

Taken together the number of fishermen, the income they derive from the activity, improved protein supply but also the employment opportunity in times of scarcity as well as the capital to reinvest in other livelihood strategies leads to the conclusion that fishing in the study communities is not only of incidental benefit, as it used to be traditionally, but can be developed into an important livelihood support strategy. Further, at least in the dry season, the activity lifts the people above the lower poverty line. 
For the fishmongers the picture looks different. Although those involved in trading fish assign a high importance to the activity, the percentage of women involved is rather low. Yet it is more than an incidental benefit. It should be considered rather as a small scale operation which builds a crucial part of their livelihood portfolios.

As pointed out in above, over one third of the reservoirs initially visited are not used for fisheries at all. This paper shows that once people can access the fisheries resources in these reservoirs, a significant number of people gain an additional livelihood strategy. Based on these findings this paper recommends the expansion of government and donor efforts toward the training of members of those communities which are currently not able to access their fisheries resources due to the lack of know-how and fishing gear.

However, in order to further increase the potentials of fishing as a livelihood strategy, efforts should also include the establishment of fisheries management regimes. Management strategies could include setting up no-catch zones in the reservoirs, refuge where fish can hide and breed. These nocatch zones could be marked with heavy tree stems, too heavy to just push them aside and with lots of branches, so that the fishermen would not be tempted fish there, as the branches would get stuck and tear the nets. In addition, fishermen could feed these places to enhance reproduction and growth. Feed that is rather easily available and not too expensive would be the mash from the locally brewed beer (pito) or weed bran. A second important measure is, to not totally fish out the reservoir in the dry season, but rather leave some larger adult fish as breeding stocks. The water body could also be excavated in some places to provide the remaining stock in the dry season with better survival chances. Another measure is the adherence of the ban on fishing in the main reproductive season and of course the net mesh-size regulations and gear limitations.

While these measures can to some extent counteract problems of over-fishing, resolving the health problems associated with fishing as a livelihood strategy need further research.

\section{REFERENCES}

Ackah, C. and Appleton, S. (2003). "Food Price Changes and Consumer Welfare in Ghana in the 1990s." CREDIT Research Paper, 07(3): pp. 1-37. Nottingham.

Antwi, V. (2006). “Country Case Study: Ghana." In U. Kleih, P. Greenhalgh, A. Marter, \& N. Peacock (Ed.), Sustainability Impact Assessment of Proposed WTO Negotiations. (Final Report for the Fisheries Sector Study). [online]. Available: www.sia-trade.org/. DA: 28th April 2008.

Armar-Klemesu, M., Rikimaru, T., Kennedy D. O., Harrison, E., Kido, Y. and Takyi, E.E.K (1995, March). "Household food security, food consumption patterns, and the quality of children's diet in a rural northern Ghana community". Food and Nutrition Bulletin, 16 (1): pp. 27-33.

Bacho, F.Z.I. (2004). "An exploratory survey of small scale off-farm economic activities and sustainable household livelihoods in the Bongo district of Ghana". Ghana Journal of Development Studies 1(2): pp. 27-49.

Bacho, F.Z.L. and Bonye, S. (2006). "From Public Open Access To Common Property: The Prospects And Challenges Of Institutionalizing Boundaries For Self-Governance And Management Of Community Irrigation Dams In The Upper East Region, Ghana." Ghana Journal of Development Studies 3(1): pp. 102-118. 
Baijot, E., Moreau, J. and Bouda, S. (1997). "Hydrobiological aspects of fisheries in small reservoirs in the Sahel region." Technical Centre for Agricultural and Rural Cooperation ACP-EU, Wageningen. [online]. Available:

http://www.anancy.net/documents/file_en/828_Hydrobiological_aspects_of_fisheries_in_small_res erv.pdf. DA: $18^{\text {th }}$ July 2008.

Barrett, C.B. and Arcese, P. (1998). "Wildlife harvest in integrated conservation and development projects: Linking harvest to household demand, agricultural production and environmental shocks in the Serengeti." Land Economics 74(4): pp. 449-465.

Biederlack, I. and Rivers, J. (2009). "Comprehensive Food Security and Vulnerability Analysis (CFSVA)." World Food Program. [online]. Available:

www.reliefweb.int/rw/RWFiles2009.nsf/FilesByRWDocUnidF ilename/EGUA-7RYMKVfull_report.pdf/\$File/full_report.pdf. DA: 13th April 2009.

Blench, R.M. (2006). "Working paper: background conditions in Upper East region, Northern Ghana, 2005." [online]. Available:

http://www.rogerblench.info/Development/Ghana/IFAD/LACOSREP/Blench\%20UER\%20w orking\%20paper.pdf. DA: 10th December 2007.

Braimah, L.I. (1990). "Modern and traditional fisheries management systems in the Sahelian zone of Ghana." Paper presented at the FAO/CIFA Seminar on Traditional and Modern Fisheries Management Systems in the Sahel, FAO, 7-10 May 1990.

Brashares, J.S., Arcese, P., Sam, M.K., Coppolillo, P. B., Sinclair, A.R.E. and Balmford, A. (2004, November). "Bushmeat Hunting, Wildlife Declines, and Fish Supply in West Africa." Science, 306: pp. 1180-1183.

COFAD (2002). "Back to Basics: Traditional Inland Fisheries Management and Enhancement Systems in Sub-Saharan Africa." [online]. Available: www.cofad.de/download/backtobasicsweb.pdf. DA: 5th March 2006.

Department for International Development (ed.) (1999). "Sustainable Livelihoods Guidance Sheets". London. [online]. Available: livelihoods@dfid.gov.uk. DA: 15th August 2010.

Dickson, K.B. and Benneh, G. (2004). A New Geography of Ghana. (5th ed.). London: Longmans Group Limited.

Ellis, F. (2000). Rural Livelihoods and Diversity in Developing Countries. New York: Oxford University Press.

Essuman, K.M. (1992). "Fermented fish in Africa. A study on processing, marketing and consumption." FAO Fisheries Technical paper 329. Rome: FAO.

Fortes, M. (1959). Oedipus and Job in West African Religion. Cambridge: Cambridge University Press.

Ghana Statistical Service (2000). Ghana Living Standard Survey. Report of the Fourth Round (GLSS 4). Accra: Ghana Statistical Service.

Grindal, B.T. (2003). Why the Young leave Home: Witchcraft, Authority, and the Ambiguity 
of Evil in Sisalaland. In F. Kröger \& B. Meier (Ed.), Ghana's North. Research on Culture, Religion, and Politics of Societies in Transition. Frankfurt: Peter Lang Verlag, pp 45-60.

Gyasi, K.O. (2005). Determinants of Success of collective actions on Local Commons: An Empirical Analysis of community based Irrigation Management in Northern Ghana. Frankfurt: Peter Lang Verlag.

Hardiman, M. (2003). Konkonuru - Life in a West African Village. The Impact of Socioeconomic Change on Rural Communities. Accra: Ghana University Press.

Hauck, J. and Youkhana, E. (2010). Claims and reality of community-based water resources management: A case study of rural fisheries in Ghana. In D.M. Nanang \& T.K. Nunifu (Ed.), Natural Resources in Ghana: Management, Policy and Economics. New York: Nova Science Publishers.

Hesselberg, J. and Yaro, J.A. (2006). An assessment of the extent and causes of food insecurity in northern Ghana using a livelihood vulnerability framework. GeoJournal, 67, pp. 41-55.

Holtkamp, T. (1994). Dezentralisierung und Partizipation in Ghana. Saarbrücken, Fort Lauderdale: Breitenbach Verlag.

Hunter, J.M. (2003). Inherited burden of disease: agricultural dams and the persistence of bloody urine (Schistosomiasis hematobium [sic]) in the Upper East Region of Ghana, 19591997. Social Science and Medicine, 56 (2), pp 219-234.

Klages, J. (1953). Navrongo. Ein Afrikabuch mit 108 Aufnahmen. Zurich: Rotapfel Verlag.

Kunstmann, H. and Jung, G. (2005). "Regional Hydrological Impacts of Climatic Variability and Change". Proceedings of symposium 56 held during the Seventh IAHS Scientific Assembly at Foz do Iguaçu, Brazil, April 2005, IAHS Publications 295: pp. 1-11.

Laube, W. (2007). Changing Natural Resource Regimes in Northern Ghana. Actors, Structures, Institutions. Berlin: LIT.

Liebe, J., van de Giesen, N. and Andreini, M. (2005). "Estimation of small reservoir storage capacities in a semi-arid environment. A case study in the Upper East Region of Ghana." Physics and Chemistry of the Earth 30: pp. 448-454.

Massing, A.W. (1994). "Local Government Reform in Ghana: Democratic Renewal or Autocratic Revival?." Cologne Development Studies, 21. Saarbrücken: Verlag für Entwicklungspolitik.

Mdemu, M.V., Rodgers, C., Vlek, P.L.G. and Borgadi, J.J. (2009). “Water productivity (WP) in reservoir irrigated schemes in the upper east region (UER) of Ghana." Physics and Chemistry of the Earth 34: pp 324-328.

Meier, B. (2003). Living in the Bush: Representations of Urban Life among Northern Ghanaian Migrants. In F. Kröger \& B. Meier (Ed.), Ghana's North. Research on Culture, Religion, and Politics of Societies in Transition. Frankfurt: Peter Lang Verlag: pp 61-78. 
Mensah, M.A., Koranteng, K.A., Bortey, A. and Yeboah, D.A. (2006). The State of World Fisheries from a Fishworker Perspective: The Ghanaian Situation. SAMUDRA Monograph 39. [online]. Available: http://icsf.net/icsf2006/uploads/publications/monograph/pdf/englis h/issue_39/ALL.pdf. DA: 3rd April 2009.

Milner-Gulland, E.J., Bennett, E.L. and the SCB 2002 Annual Meeting Wild Meat Group (2003). "Wild meat: the bigger picture." Trends in Ecology and Evolution 18(7): pp. 351-357.

Norton, A., Bortei-Doku Aryeetey, H., Korboe, D. and Dogbe, D.K. (1995). Poverty Assessment in Ghana Using Qualitative and Participatory Research Methods. PSP Discussion Paper Series 83, Washington DC: World Bank.

Tonah, S. (1994). "Agricultural Extension Services and Smallholder Farmers' Indebtedness in Northeastern Ghana." African and Asian Studies 29(1-2): pp. 119-128.

Van de Poel, E., Hosseinpoor, A., Jehu-Appiah, C., Vega, J. and Speybroeck, N. (2007). Malnutrition and the disproportional burden on the poor: The case of Ghana. International Journal for Equity in Health, 6 (21).

World Bank (2007). Ghana Meeting the Challenge of Accelerated and Shared Growth. Country Economic Memorandum, Volume II: Background Papers. Report No. 40934-GH. Washington.

Yaro, J.A. (2007). Peasant Livelihoods and Land Degradation: Evidence from a Participatory Assessment in the Gia-Kajelo Community in Northern Ghana. West African Journal of Applied Ecology 11. [online]. Available:

http://www.wajae.org/papers/paper_vol11/Peasant\%20Livelihoods.pdf. DA: 30th October 2008. 